\title{
“QUIZÁS, QUIZÁS, QUIZÁS”. TRANSLATORS' DILEMMAS AND SOLUTIONS WHEN TRANSLATING SPANISH SONGS INTO ENGLISH ${ }^{1}$
}

\begin{abstract}
Jean Stephenson ${ }^{2}$
Abstract: Rendering songs into another language poses numerous difficulties for translators. Songs may be considered as poems set to music, and in translating them, these professionals confront not only routine translation problems such as expressing the meaning, ambience and style of the original work, but they also have to attend to other requisites such as creating a new version of the song within the restrictions of rhythm and rhyme. In this article, I examine songs from Spanish literature and from Spanish and South American popular music, and explore translators' ways of converting the original texts into English. We shall see that sometimes they have captured meaning by translating virtually word for word, while on other occasions translated songs manage to encapsulate only the general sense and atmosphere of the original Spanish song. In some cases, sounds from the original have acted as a catalyst for the topic of a new song, while in others the song's main topic has been discarded altogether. As a result of these perhaps inevitable adjustments and shifts in topic and atmosphere there will nearly always be some kind of 'loss' in the translation of songs, but on rare occasions their rendition into English almost seems to 'improve' on the Spanish version. I will outline Low's (Low, 2005) "Pentathlon Principle" which offers five criteria for assessing song translation, and examine specific translations from this persective. Song examined are María Josefa's song "Ovejita, niño mío" from Federico García Lorca's "La Casa de Barnada Alba", Luis Aguilé's "Cuando salí de Cuba", Agustín Lara's "Granada”, and Osvaldo Farrés's "Quizás, quizás, quizás."
\end{abstract}

Keywords: songs; Spanish-English translation

Resumen: La traducción de las canciones presenta numerosos problemas para los traductores. Se pueden considerar las canciones como poemas musicales, y al traducirlas, los traductores no solo abordan las dificultades rutinarias de su profesión tales como expresar el significado, el ambiente y el estilo de la obra original, sino también deben crear una nueva versión de la canción dentro de las restricciones del ritmo y de la rima. En este artículo examino algunas canciones de la literatura española y canciones populares de España y Sudamérica y comento los métodos utilizados por los traductores a la hora de convertir en cada caso la letra española en un texto nuevo y listo para ser cantado en inglés. En su búsqueda de expresar el significado de la canción, veremos que a veces el traductor ha optado por traducir palabra por palabra, mientras que otras veces ha logrado captar solo el sentido general de la obra original. En algunos casos el sonido de

Stephenson, J. (2014). “Quizás, quizás, quizás”. Translators' dilemmas and solutions when translating Spanish songs into English. DEDiCA. REVISTA DE EDUCAÇÃO E HUMANIDADES, 6 (2014) março, 139-151 
una palabra española ha inspirado todo un tema nuevo, y en otros el tema de la canción española ha sido abandonado por completo en su versión inglesa. Como resultado de estos desvíos y ajustes en la traslación de una canción de una lengua a otra, es casi inevitable alguna que otra pérdida en la traducción, pero en muy contadas ocasiones la traducción quizás dé lugar a mejoras en la canción nuevamente creada. Describo el "Pentathlon Principle" de Low (Low, 2005), en el que este autor ofrece cinco principios para la evaluación de la traducción de las canciones, y examino algunas traducciones desde esta perspectiva, comentando las versiones en inglés de algunas canciones en lengua española, entre ellas, "Ovejita, niño mío" de María Josefa de "La Casa de Bernarda Alba" de Federico García Lorca, "Cuando salí de Cuba" de Luis Aguilé, "Granada" de Agustín Lara y "Quizás, quizás, quizás" de Osvaldo Farrés.

Palabras clave: canciones; traducción español-inglés

\section{Introduction}

Songs, considered as poems set to music, pose special challenges for translators. Not only must these professionals solve the more 'usual' translation problems of conveying meaning, atmosphere, and style of the original, but they also have to address other demands such as creating a translated text within the constraints of rhythm and rhyme. In some cases translators have adhered to meaning by translating virtually word for word, while others have managed to capture the general sense and ambience of the original Spanish song. In some translated songs, sounds from the original have acted as a springboard for the topic of the translated song, while in others the song's major theme has been ignored altogether. In contrast to these alterations undertaken in most song translations, which result perhaps inevitably in some kind of 'loss', on rare occasions the rendition into English may seem to better some elements of the original Spanish song.

\section{The song translator's task}

It goes without saying that a translator must bear in mind that his/her rendering of a song from one language into another must be sung. The writing of a new singable creation is an extemely complicated task, because, according to Peter Low (Low, 2005: 184) it "must fit the pre-existing music [...] while still retaining the essence of the source text." This author proposed that a singable translation is an extremely difficult endeavour due to the many constraints imposed by elements of the music (e.g., pitch, melody and rhythm). Low considers song translation to be a "practical craft", and building on other research (Dyer-Bennet, cited in Emmons; Sonntag, 1979), 
he outlines what he calls a "practical skopos-based approach to the devising of singable translations" (Low, 2005: 191).

\section{The "Pentathlon Principle"}

According to Low, the great issue in translating songs is "balancing several major criteria which often conflict" (Low, 2005: 191). For him, song traslators are like Olympic pentathletes: s/he has five 'events' in which to compete, and five criteria with which to comply, and his/her objective is to achieve the best possible total overall score. The five 'events' are (1) singability; (2) sense; (3) naturalness; (4) rhythm; (5) rhyme. These 'events' are dissimilar and translators face the challenge of reaching a satisfactory equilibrium amongst them. Low points out that "[translators] may sometimes choose to come second or third in one event, keeping their eye on the whole day's challenge. They do not often achieve [...] world class results in a single event. One quality they must develop to a high standard is flexibility" (Low, 2005: 192).

\section{(1) Singability}

Here the translator fulfils his/her duty to the singer. This is the "top ranking" (Low, 2005: 192) element in this kind of translating, and is a totally pragmatic issue, requiring song performability for the sake of the singer. Low points out, for example, that consonant clusters may be hard for the singer to pronounce with ease, so the translator may sacrifice such words at the expense of a precise translation of meaning. Also, the translator may want to avoid placing "under-sized vowels" (Low, 2005: 191) on long, slurred or emphatic notes (for example, s/he may decide to place "the" or "it" on a quaver but not on a minim). Gorlée (Gorlée, 2002: 167) has pointed out that some singers say that it is difficult to sing certain vowels on very high notes, while other vowel sounds are said to have poorer quality if sung on low notes. In addition, Low advises that words in the original song given "prominence by musical means", for example, "high pitched or fortíssimo [...] should be highlighted at the same location" in the translation (Low, 2005: 193).

\section{(2) Sense}

In this regard, the translator does his/her duty to the author. With ordinary texts, meaning is of paramount importance, whereas in songs the translator may take liberties with the original sense. This is done in order to accommodate the positioning of words on syllables as suggested by the melody. As Low maintains: "In a genre where

"Quizás, quizás, quizás". Translators' dilemmas and solutions when translating Spanish songs into English 
syllable-count is important, the need to stretch sense arises [...] naturally" (Low, 2005: 194). For example, a word may be translated by a "near-synonym", or a "narrow term by a superordinate term" (Low, 2005: 194). In some instances, sense has been ignored altogether. In the latter case, Low considers that "this is not translating because none of the original verbal meaning is transmitted" (Low, 2005: 194).

\section{(3) Naturalness}

This component of the Pentathlon Principle has to so with the song translator's "duty to the audience, the receivers of the musico-verbal message" (Low, 2005: 195). Naturalness spans issues such as "register and word order" (Low, 2005: 195), and Low advocates avoiding "translationese", that is, paying too much attention to semantic accuracy. A song translation must convey its message adequately on the first hearing through naturalness of language, because unnaturalness demands of the listener extra and unnecessary processing effort (Low, 2005).

\section{(4) Rhythm}

This concerns the translator's respect for the composer. Any song has its own rhythm as created by the composer, and this will naturally determine the rhythm in which the source text is developed. And translators of this original text must in turn also respect the composer in that their new lyrics must be placed on this pre-existing rhythm. In this regard Low thinks that using the exact syllable count is desirable but he advocates flexibility: the translator may elect to add or subtract syllables. Modifying the tune is "not of the question either" (Low, 2005: 197). He claims that even discreet "tweaking" may take place in order to prevent a "glaring verbal gaffe." If there are too few syllables for ease of translation, any words aggregated to the target text must "give the appearance of coming from the subtext of the source" (Low, 2005: 197). Traslators must attempt to replicate syllable stress where it fell in the original lyrics. S/he must also cater for the duration of notes, and take into account rests occurring in the source text: any gap in the translation must not be placed in such a way that might split a word in two (Low, 2005: 198). 


\section{(5) Rhyme}

In Low's opinion, rhyme is a "special case" (Low, 2005: 198). As far as this component of the Pentathlon Principle is concerned, it "opposes rigidity of thinking" (Low, 2005: 198). In this regard, Low advocates flexibility, and recommends that rhymes need not occur in the same locations or with the same frequency as they do in the source song. Rhymes in translation do not have to be as pristine as in the the original lyrics, and the song's whole rhyme scheme may be altered. The same phonemic combinations need not be located at the end of every line, and these slightly less-than-perfect rhymes may be a suitable remedy because in this way less meaning may be lost in translation. Low gives the example of 'above' which would be an optimal rhyme of 'love', but 'enough' or 'move' might be fitting (Low, 2005: 199). Also acceptable are rhyme's cousins (Apter, 1985: 309-310), such as off-rhymes (line- time,); weak-rhyme (mayorsqualor); half-rhyme (kitty-knitted); consonant rhyme (slit-slat). In this way, the translator will not force a translation to sound too exaggerated, fanciful, or distant from the source text.

\section{Some examples of Spanish songs translated into English in the light of Pentathlon Principles}

Singability. An example of a very singable song translation from the Pentathlon viewpoint is "Quizas, quizás, quizas" (Osvaldo Farrés, 1947), translated into English by Joe Davis (1949) as "Perhaps, perhaps, perhaps".

"Y así pasan los días

y yo, desesperado

y tú, y tú, tú

contestando

quizás, quizás, quizás” (Farrés, 1947).

"So if you really love me

Say yes

But if you don't, dear, confess,

And please don't tell me

Perhaps, perhaps, perhaps" (Davis, 1949). 
Stresses tend to mirror spoken speech in both the original and in the translation (" $y$ así pasan los días, $y \underline{y o}$ "/ And if you really love me, say yes"), facilitating performance for the singer. If "desesperado" were translated literally ("desperate"), not only would a syllable be missing in that line, but also the performer would be in the awkward position of having to sing two unstressed schwas on two long notes (/'despərət/), so the translator has wisely avoided using this word. The low notes on the "a" of "quizás" are not too difficult to sing, and equally in the translation, these low notes fall on the helpfully open "a" of "perhaps".

Sense. Some songs from Spanish literature have been rendered in English almost word for word, giving rise to a text that embraces virtually the whole of the original sense. For example, María Josefa's song in "La Casa de Bernarda Alba":

"Ni tú ni yo queremos dormir.

La puerta sola se abrirá y en la playa nos meteremos en una choza de coral" (Federico García Lorca, 1936: 122),

is translated by Michael Dewell and Carmen Zapata (1992: 163) as:

"You and I don't want to sleep;

The door will open on its own

And you and I will hide ourselves

In a hut made of coral on the beach."

As may be observed, by Pentathlon Principle standards, the translators of Josefa's song have chosen to give first place to sense in this 'event'. However, an illustration of a song translation in which sense has been disregarded completely is "Cuando salí de Cuba" by Luis Aguilé (1969). While the original lyrics go:

"Cuando salí de Cuba

dejé mi vida,

dejé mi amor.

Cuando Salí de Cuba

dejé enterrado mi corazón" (Aguilé, 1969),

the translation has been rendered thus: 
"Once on a Sunday morning

Before the sunlight was in the air, Once on a Sunday morning

Before my eyes she was standing there" (Tremeloes, 1970).

Here no flexibility has been used: the meaning of the original has simply been abandoned. The translator has written a text which goes nicely with the music but which bears no resemblance to the theme of the original. This song in Spanish is about the 'singer's' heart being left behind and buried in Cuba, perhaps making an oblique political statement about a Cuban in exile. The English lyrics, beginning "Once on a Sunday morning", were perhaps inspired by the slight resemblance of sound between the first Spanish word "Cuando" and the English "Once". But here the similarity ends and the translator of the English lyrics has taken the song off on a completely different tangent. Low would consider that "this is not translating because none of the original verbal meaning is transmitted" (Low, 2005: 194).

Naturalness. A song translation which I consider would probably score highly in the naturalness 'event' is "Yesterday I heard the rain", Gene Lees's (1968) rendering of the original "Esta tarde vi llover" by Armando Manzanero (1968). Song lyrics should make an immediate impact on listeners when they first hear them and this is achieved by Lees. His translation keeps to the song's theme, but his unfettered expression sounds smooth and effortless. The verb + particle ("walked on") used in the lines I quote below sounds particularly natural:

"Yo no sé cuánto me quieres,

si me extrañas

o me engañas.

Sólo sé que vi llover,

vi gente correr

y no estabas tú " (Manzanero, 1968).

"I walked on through the city

Full of shadows, without pity

And I heard the steady rain,

Whispering your name, 
Whispering your name" (Lees, 1968).

Rhythm. The handling of syllable count in "Quizás, quizás, quizás" (Farrés, 1947) gives an example of how these can be added or taken away to accommodate the rhythm of a line. Notice that the seven syllables of " $y$ tú, tú contestando" are reduced to five in "And please don't tell me":

Y así pasan los días y yo (9 syllables)

desesperando y tú, (7)

y tú, tú contestando (7)

quizás, quizás, quizás (7) (Farrés, 1947).

So if you really love me, say yes (9)

But if you don't, dear, confess, (7)

And please don't tell me (5)

Perhaps, perhaps, perhaps (6) (Davis, 1949).

Rhyme. Observe how Gwynne Edwards and Henry Livings (1994) bestow on their English translation of the children's chant in Federico García Lorca's Mariana Pineda (1927) the same rhyme scheme as in the original (ABCB).

"¡Oh, qué día triste en Granada,

Que a las piedras hacía llorar,

al ver que Marianita se muere

en cadalso por no declarar!" (García Lorca, 1927, in Arturo del Hoyo, 1957: 801).

"How sad it was in Granada!

The stones began to cry;

They could not make Mariana speak,

And so she had to die" (Edwards; Livings, 1994: 54).

The Pentathlon Principle and "Granada" (Lara, 1932)

Let us now consider Dorothy Dodd's (1951) translation of the the song "Granada" by the Mexican composer Agustín Lara (1932) from the Pentathlon Principle (Low, 2005) viewpoint, assessing how it fares as regards sense, singability, naturalness, rhythm, and rhyme.

As far as sense is concerned, "Granada" is a song which praises the Spanish city of the same name: it is the land of my 
dreams and is personified by a dark, bewitching and beautiful woman, both gypsy and Moorish:

"Tierra soñada por mí [...]

Te sueño, rebelde, gitana [...]

Mujer que conserva el embrujo de los ojos moros."

The singer 'addresses' the city of Granada ("Mi cantar se vuelve gitano cuando es para ti") as if she were a woman, expressing passionate love, kissing her scarlet mouth which is like a juicy apple that speaks of other loves, and covering her body with flowers:

"Y beso tu boca de grana, jugosa manzana que me habla de amores"

while conveying at other points in the song an almost religious adoration for Granada, maintaining that the city would be a fitting backdrop for the "Virgen Morena" (Dark Virgin, or Virgen de Guadalupe) of Mexico:

"De rosas de suave fragancia que le dieran marco a la Virgen Morena".

This duality of emotion felt for the city is symbolised in the passionate blood of the bullfight, and in the restrained melancholy of a flower, found elsewhere in the song:

"Tierra ensangrentada en tardes de toros"

"Mi cantar, flor de melancolía que yo te vengo a dar".

As regards the sense of Dodd's (1951) translation of "Granada", there are some points of comparison, but in general, the lyrics give us a different perspective on the city. As in the original, the lyrics of "Granada" in English are 'addressed' to the city, it is a song of praise, and evokes the city's magic and allure:

"Granada, I'm falling under your spell

And if you could speak

What a fascinating tale you could tell", 
but it refers much more directly to its physical and perhaps historical attributes than the Spanish song, and gives no hint of the symbols of passion and religious adoration found in the original text. Dodd's lyrics take the listener through the past and up to the present:

"Of an age the world has long forgotten,

Of an age that weaves a silent magic in Granada today"

and through one whole day:

"The dawn in the sky greets the day with a sigh [...]

And when day is done and the sun starts to set..."

The English song also describes the physical beauty of the city and its surroundings, much more so than Lara's more abstract evocation:

"The hills all around as I wander along [...]

This land full of sunshine and flowers [...]

The blush on the snow-clad Sierra Nevada".

From the singability viewpoint, both the Spanish original and the English translation of "Granada" are extremely singable. They both have dramatic words and melody, and they lend themselves to many styles (ballad, jazz, pop, easy listening, operatic styles). Both versions have been recorded and sung live by scores of artists over the decades since the Spanish and English versions were composed and translated, respectively. Low (Low, 2005) would be pleased to note that there are open vowels throughout the English version, and few consonant clusters. The word "Granada" (and the stressed second "a" of this word) is sung on the climax of the introduction ("in Granada today"). For the singer there is the excitement of singing Spanish words in an English song (Sierra Nevada, Habanera), and the repetitions of words are dramatic:

"of an age the world has long forgotten, of an age that weaves a silent magic"

"entranced by the beauty before me, entranced by this land full of sunshine and flowers and song." 
Low (Low, 2005: 193) advised that words given prominence by musical means (for example, sung on high notes or fortíssimo) should be stressed at same place in the translation. Dodd carried out this procedure throughout her translation. For instance, the line "Granada, tu tierra está llena" is accented on "llena", and is highlighted at the same place in "Then moonlit Granada will live again" in the translation. In one place at least, Lara's "Granada" is less "singable" than Dodd's version. At the end of the introduction, the line "que yo te vengo a dar" (highlighted on "vengo") is rendered as "In Granada today". I would maintain that here it is easier to sing the "a" (English version) than the "é" (Spanish original) on such a high, long and transcendental note.

In the naturalness event of the Pentathlon, both the original song and the translation would probably score highly. Lara's creation evokes drama, passion and vibrancy, a 'typical' conception, as it were, of Granada (Lara still had not visited Granada in 1932, when he composed this song). Dodd's lyrics seem to reflect the memories of someone who has actually been to the city.

In considering rhythm when she translated "Granada", Dodd used a flexible approach, again in line with Pentathlon criteria. She mostly respected the exact rhythm and number of syllables:

"Granada tierra soñada por mi” (10 syllables)/“Granada, I'm falling under your spell" (10)

"Mujer que conserva el embrujo de los ojos moros" (15)/ "I still can remember the splendour that once was Granada" (15)

She sometimes subtracts syllables:

"Mi cantar se vuelve gitano" (9) / "and if you could speak" (5) and sometimes adds them:

"Cuando es para ti" (6) / "What a fascinating tale you would tell" (10).

Once more taking into account Pentathlon recommendations, Dodd has not necessarily set her rhymes in the same places or with the same frequency as in Lara's song. For example, let us consider these two lines from the Spanish "Granada": 
"Granada, manola, cantada, en coplas preciosas. No tengo otra cosa que darte que un ramo de rosas".

The internal rhyme scheme on the first line is abab. The rhyme scheme on the two lines is CC. At this point in her translation, Dodd reduces the internal rhyme on the first line with "done"/"sun" (aa), but maintains the end-of-line scheme with "-nada"/ "-vada" (BB):

"And when day is done and the sun starts to set in Granada I envy the blush of the snow clad Sierra Nevada".

Some of Dodd's rhymes are not perfect. Indeed, at some points she does not attempt to use rhyme at all where it existed in the original:

"Y beso tu boca de grana, jugosa manzana"

"Entranced by the beauty before me, entranced by this land full of..."

On occasion she inserts an 'off-rhyme' where none was present in the Spanish original:

"Mujer que conserva el embrujo de los ojos moros".

"I still can remember the splendour that once was Granada".

\section{Conclusion}

As a very tentative conclusion, after judging the elements of Dorothy Dodd's (1951) translation of Agustín Lara's (1932) "Granada" as if they were five events of a pentathlon in line with Low's (Low, 2005) principles, I would assess them as follows:

- Sense: moderate/moderate to low score

- Singability: high score

- Naturalness: high score

- Rhythm: very high score

- Rhyme: high score.

I invite readers to make their own evaluation of "Granada" and hope that they will be pleased to appraise other song translations in the same way. 


\section{References}

Emmons, S.; Sonntag. S (1979). The Art of Song Recital. New York: Schirmer.

García Lorca, F. (1936). La Casa de Barnarda Alba. Barcelona: Edición Planeta deAgostini (2004).

García Lorca, F. (1957). Obras Completas. (Recopilación y Notas de A. del Hoyo). Madrid: Aguilar.

García Lorca, F. (1992). Three Plays (Translated by M. Dewell; C. Zapata). London: Penguin Books.

García Lorca, F. (1994). Three Plays: Mariana Pineda . The Public - Play without a title (Translated by G. Edwards; H. Livings). London: Methuen World Classics.

Gorlée, D. L. (2002). Greig's swan songs. Semiotica, 142 (2002) 1/4, 153-210.

Low, P. (2005). The Pentathlon approach to translating songs. In D. L. Gorlée (Ed.), Song and Significance. Virtues and Vices of Vocal Translation, 185-212. Amsterdam - New York: Editions Rodopi.

\footnotetext{
1 “Quizás, quizás, quizás”. Dilemas en la traducción de las canciones españolas al inglés

${ }^{2}$ Doctora.

Universidad de Granada (España).

E-mail: jstephen@ugr.es
} 